\title{
Melhoria no uso de antimicrobianos em hospital privado
}

Autores: Maria Lucia Neves Biancalana, Andre Koutsodontis Machado Alvim, Michel Laks; Ingvar Ludwig Augusto de Souza e Felipe Silva Duraes.

\section{Sobre a instituição}

A BP - A Beneficência Portuguesa de São Paulo é um polo de saúde composto por 4 hospitais e 3 outros serviços de saúde e de educação e pesquisa. Fundada em 1859, a BP possui 8.000 colaboradores, 4.500 médicos cadastrados e oferece serviços de saúde privados e para clientes encaminhados via regulação pelo Sistema Único de Saúde (SUS).

\section{Introdução}

O uso racional de antimicrobianos visa oferecer melhor cuidado ao paciente, reduzir a seleção de agentes resistentes, a incidência de infecção por Clostridium difficile e otimizar recursos financeiros para a instituição.

O apoio da alta direção é essencial para a implantação de programa de uso racional de antimicrobianos, fornecendo recursos humanos e tecnológicos necessários e apoiando os responsáveis pelo controle em situações de embate com o corpo clínico.

\section{Objetivo}

Descrever um conjunto de medidas que contribuíram para a redução do uso de antimicrobianos e os resultados obtidos em três anos de acompanhamento.

\section{Metodologia}

A partir de 2015 o controle do uso de antimicrobianos foi aperfeiçoado, incluiu

farmacêuticos e as seguintes ações:

- Monitoramento e controle da antibioticoprofilaxia cirúrgica

- Necessidade de justificativa para a prescrição de antibióticos e antifúngicos de amplo espectro;

- Elaboração de manuais para antibioticoprofilaxia e antibioticoterapia pelos médicos do Serviço de Controle de Infecção Hospitalar;

- Retorno para as equipes médicas sobre seu perfil de utilização de antimicrobianos e

antibioticoprofilaxia;

- Educação continuada para equipe

multidisciplinar;

- Monitoramento dos custos relacionados aos antimicrobianos controlados;

- Divulgação de indicadores sobre o uso de antimicrobianos para lideranças médicas e administrativas.

\section{Resultados}

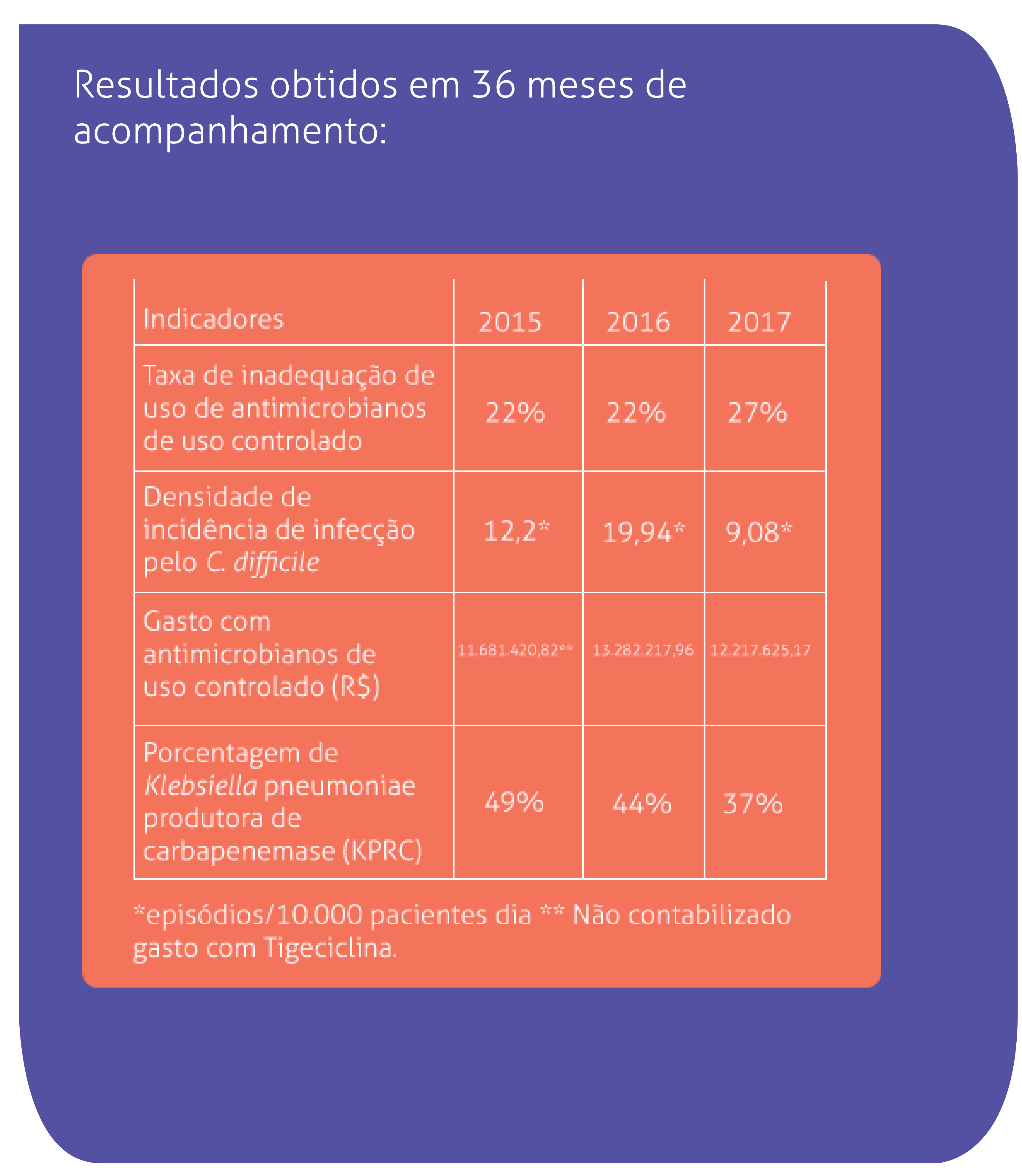

\section{Conclusão}

Um conjunto de ações coordenadas e multidisciplinares envolvendo o uso de antimicrobianos e o apoio da alta direção do hospital contribuem para redução da resistência bacteriana, do dano ao paciente e do gasto com medicamentos.

\section{Referências:}

-Clinical Infectious Diseases 2016:62(10): e51-e77

- Diretriz Nacional para Elaboração de Programa de Gerenciamento do Uso de Antimicrobianos em Serviços de Saúde (ANVISA) 2017 